\title{
THE ROLE OF EXFOLIATIVE CYTOLOGY IN THE DIAGNOSIS AND TREATMENT OF MALIGNANT DISEASE
}

\author{
Elizabeth A. McGrew, M.D. \\ Associate Professor of Pathology, University of Illinois College of Medicine, Chicago 12, Illinois, U.S.A.
}

THE study of cells derived from the various lining and covering surfaces of the body dates back to the days of the first microscope, for surely, cells scraped from the lining of the mouth and from other areas were among the first wonders to be observed with the new contrivance. Detailed observation of exfoliated cells was first undertaken by Pouchet, however, who in 1847 , reported the changes occurring in unstained vaginal smears during the female sex cycle. This kind of material was but little used thereafter, until 1917, when Stockard and Papanicolaou published the first of a series of articles on cyclic changes in vaginal smears. These studies contributed materially to our present understanding of the mammalian sex cycle.

The indentification of malignant cells in various body fluids began with the report of Beale in 1860 , that he had found particles from a malignant pharyngeal tumour in sputum, and in 1864 , Sanders recorded the discovery of malignant tumour particles in the sediment of urine. Increasing interest in the diagnostic possibilities of this method followed, particularly with reference to fluids from the pleural and peritoneal cavities. 'A Handbook of Clinical Microscopy' by Bizzozero, appearing in its second German Edition in 1887 , mentions the cellular elements to be found in sputum, urine, serous fluids and fæces with occasional reference to the possible identification of tumour cells. The development of tissue sectioning technique and improved staining methods in the early I 900 s obscured the potential value of these observations, however, and the field of tissue pathology evolved.

Papanicolaou's announcement in 1928 that abnormal cells could be identified in vaginal smears from women with cancer of the genital tract fell on deaf ears generally until the classic monograph describing his methods, criteria and results was published in 1943 . In the ensuing 18 years great efforts have been extended throughout the world to put this technique to the widest possible use in the detection of malignancy of the female genital tract and also to adapt it to the solution of diagnostic problems in other areas. The publication of Papanicolaou's 'Atlas of Exfoliative Cytology' in 1954 marked the firm establishment of the method as an accepted diagnostic adjunct and an important branch of anatomic pathology.

Success in utilizing the criteria of malignancy so developed depends upon obtaining suitable cells in the fresh state, dispersing them properly on the slides and fixing immediately in the solution of ether and alcohol. If the cells are permitted to. degenerate or to dry on the slide, the importaris intranuclear features (Fig. I) differentiating benign from malignant cells cannot be visualized and cell types are difficult to distinguish. The rather delicate, but not difficult, staining procedure results in very pleasant clear pastel cytoplasmic coloration, which quite reliably differentiates squamous cells from histiocytic and other types. In vaginal smears of good quality the colour of the cytoplasm of the squamous cells assists in the evaluation of hormonal states as well, since estrogenic effect generally causes a high proportion of them to take the eosin stain. The nuclear stain is hæmatoxylin and in well fixed smears the chromatin material has a very distinct network or granular pattern.

Histopathologists are familar with many of the nuclear criteria for malignancy which can be applied to exfoliated cells, such as large nuclear size, hyperchromatism, irregular shape, duplication of nuclei and an increased ratio of nuclear to cytoplasmic area. Derangements of chromatin structure, however, are rarely of value in formalinfixed and imbedded material. In cytologic smears, the normal interphase nucleus is a smooth oval with a sharp regular wall of chromatic material and an internal structure resembling a transparent cocoon. As the stain is relatively transparent one can focus through the fine 


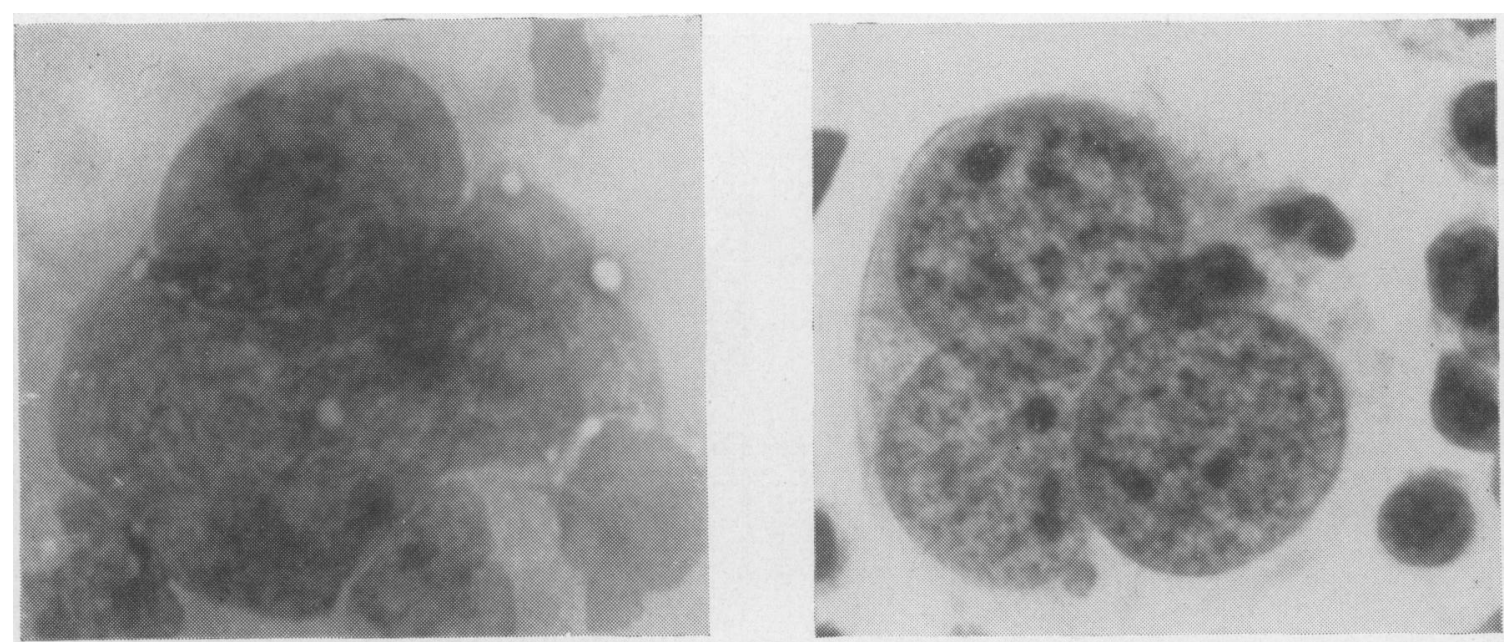

A

Reprinted with permission of the Fournal of The American Medical Womcn's Association. $\mathrm{B}$

Fig. I.-Malignant cells from two areas of the same smear of pleural fluid sediment. immersion in the fixing solution. (b) Well fixed area, Papanicolaou stain. $\mathrm{x} 2$ roo.

(a) Drying occurred beforc

fibrillar network of chromatin sharply stained against a ground-glass background. In actively proliferating cells the chromatin is more or less coarsely granular, but still evenly distributed. The nuclei of malignant cells, on the other hand, in addition to containing excessive amounts of chromatic material and assuming large irregular forms, display marked derangement of the chromatin. The nucleus may be composed of dense, opaque chromatin with no visible structure. Large nuclei generally allow resolution of the chromatin particles, which are coarse and variable in size, shape and distribution. In other instances, most of the chromatin is concentrated in a few large, irregular masses leaving most of the nucleus empty. There is also clearing of the nuclear background substance, which may be focal as if part of the nucleus had been erased (Fig. 2).

Exfoliated cells are easy to obtain from most areas of the body but another important advantage rests on the fact that body fluids generally contain cells representing large areas, while a biopsy consists only of the tissue chosen. This is particularly advantageous in urinary bladder lesions where the biopsy may represent only the superficial fronds of a tumour, and in bronchial lesions so often inaccessible to biopsy.

The chief disadvantage of exfoliative cell study in the diagnosis of malignancy is that the cells are usually isolated from one another and their growth pattern cannot be studied as it can in tissue sections. Consequently, it is best to confirm the finding of malignant cells in cytologic smears by tissue study whenever possible.

Considerable experience must bc attained in order to differentiate between malignant cells and those rendered atypical in form, size and nuclear characteristics by chronic inflammation, radiation or other agents. Indeed, the range of atypia in cells of benign lesions is great, and it is impossible to draw a distinct line at a point where all on one side are benign and all on the other side malignant. Thus, if one is very conservative, there may be no false positive cytologic interpretations, but the number of cancers missed will increase. Since, in most applications, the value of the method lies in its sensitivity in detecting otherwise silent and hidden malignancy, sacrificing this for greater reliability would deprive many patients the opportunity for successful treatment. Pathologists and clinicians alike must be prepared, therefore, to accept the consequences of an occasional false positive report.

\section{The Female Genital Tract}

As carcinoma of the uterine cervix is the second most common fatal malignancy in women, and since cervical and vaginal smears are easy to obtain, it is natural that this method has found its greatest application in the detection of female genital tract carcinoma. By the early r 950 os reports of the cytologic detection of early and clinically unsuspected carcinoma of the uterus had become somewhat monotonous. Review of almost Ioo of these articles (McGrew, Bibliography, 1952), eliminating duplications, yielded a total of 551,117 women in whom 7,042 cancers of the genital tract were found, an incidence of $1.3 \%$. Of these tumours, 3,46 I or $49 \%$ were not suspected on clinical evidence, Seventy-nine per cent. of the 

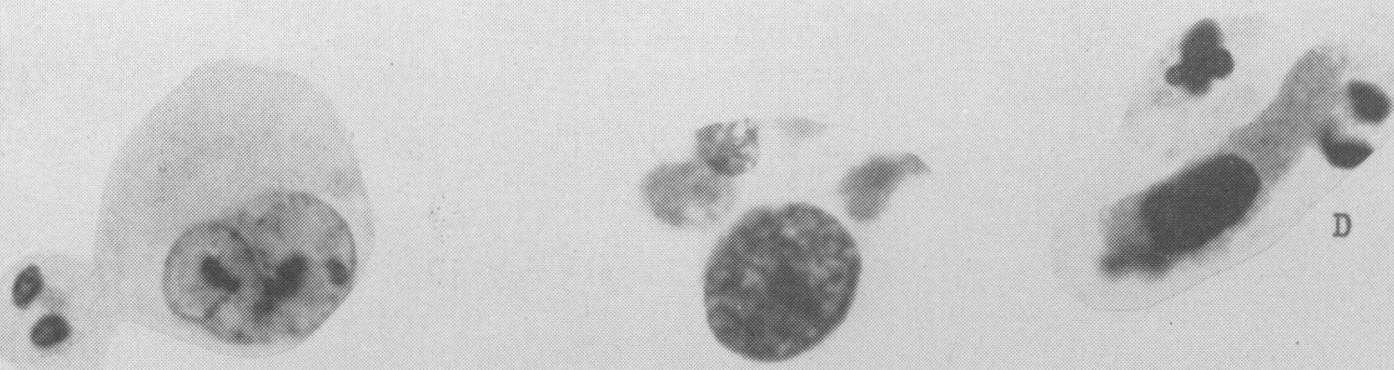

A
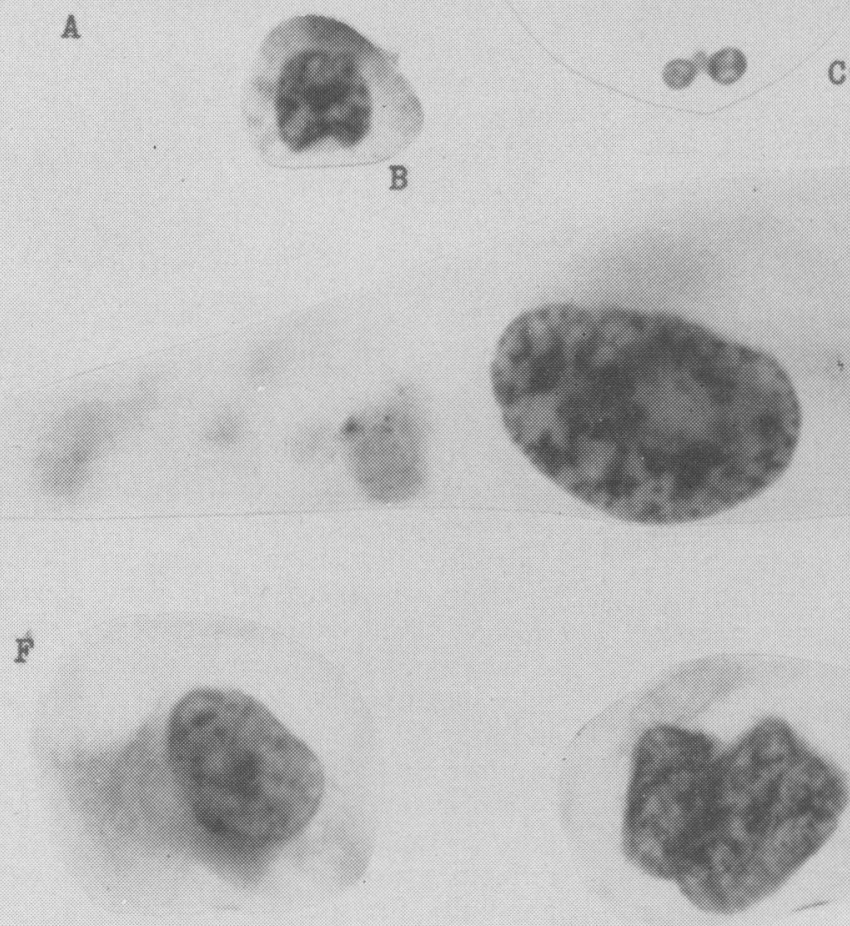

FIG. 2.-(a-e) Malignant cells. There is marked variation in size. The nuclei may be vesicular (a), and distorted (b). The chromatin may be diffuse and coarsely granular (c), opaque (d), or separated by 'erased ' areas (e). (f) Nuclear enlargement and irregular chromatin distribution in chronic inflammation. (g) Abnormal cell from atypical squamous epithelial hyperplasia. Papanicolaou stain. All cells X I400. A few polymorphonuclears are included for size reference.

unsuspected carcinomas were pre-invasive lesions of the cervix and, therefore, curable by relatively simple procedures. If these one-half million women are divided according to their clinical circumstances at the time of examination, it is found that $3.3 \%$ of women presenting themselves for examination in a gynæcologist's office or clinic have carcinoma of the genital tract. Only $17 \%$ of these lesions are unsuspected and only $12 \%$ are in the pre-invasive stage. If smears are taken routinely in the offices of general practitioners and internists, $1.5 \%$ of adult women will be found to have carcinoma of the genital tract, If the general female population of a community is surveyed, $0.8 \%$ have carcinoma, and if only women without symptoms are screened, the incidence is $0.3 \%$. In these last three groups, 50 to $60 \%$ of the tumours discovered are unsuspected on the basis of symptoms or physical examination, and 50 to $80 \%$ are in the pre-invasive stage. Even in younger age groups, screening for cervical carcinoma should not be overlooked. Slate, Martin and Merrit, in 1957, reported an incidence of two malignancies per thousand in 5,935 pregnant women. Seventy-eight per cent. of these were pre-invasive. Soule and Dahlin in 1959, screened 
over 90,000 patients coming to the Mayo Clinic without specific gynæcologic symptoms and discovered 678 carcinomas, an incidence of $0.75 \%$. A second examination was performed a year or more later on 14,400 of these women with the detection of only 27 carcinomas (0.1\% incidence), thus demonstrating the value of periodic routine pelvic examinations and cytologic smears.

It is clear, therefore, that the mortality from carcinoma of the cervix, formerly around $70 \%$, could be reduced to zero and the disease eradicated as a threat to life or health if cytologic examination were used in all women to detect the disease at a curable stage. Lund (1961) has written 'An Epitaph for Cervical Carcinoma' in which he reports the mortality from carcinoma of the genital tract reduced $20 \%$ over a nine-year period during which a community cytology project was conducted in Rochester, New York.

One of the bonus benefits of these studies is the understanding we have gained of pre-malignant and very early lesions of the cervix. The concept of pre-invasive carcinoma of the cervix was proposed many years ago but was regarded with suspicion by most pathologists who had no occasion to see it. With the advent of routine Papanicolaou smears, however, abnormal cells shed by these lesions resulted in the taking of biopsies which presented the pathologist with an array of unexpected and unfamiliar lesions. As a result, the concept of pre-invasive carcinoma has become firmly established and numerous studies have demonstrated that this lesion usually either accompanies or progresses to the invasive form. We have also come to recognize a similar, but generally reversible lesion variously called atypical hyperplasia, dysplasia, or anaplasia, which displays abnormal individual cellular characteristics but differentiates well, has few mitotic figures, and forms an epithelium which is not as thick or as crowded as pre-invasive carcinoma (Fig. 3). These interesting lesions may accompany preinvasive and invasive carcinoma or may constitute the only abnormality of the cervical epithelium. The cells exfoliating from these lesions are somewhat better differentiated than those of preinvasive and invasive carcinoma but cannot always be distinguished from them.

A word of caution is therefore in order with regard to the verification of positive cytologic findings. Abnormal cells may be found in carcinoma of the cervix in all stages of advancement, in pre-invasive carcinoma and in atypical epithelial hyperplasia. A single punch biopsy is adequate for evaluation of a patient with positive or suspicious cervical smears, only if it shows invasive carcinoma. Four quadrant biopsies are only slightly more reassuring since many pre-invasive and early invasive carcinomas arise in patches scattered throughout the endocervical lining and glands. In order adequately to evaluate the patient with positive cervical smears, a conization of the entire external os and endocervical canal without the use of cautery is necessary. The multifocal distribution of pre-invasive carcinoma and of hidden areas of invasion have been well demonstrated by Przybora and Plutowa in 1959 and Fidler and Boyd in 1960.

It should also be made clear that vaginal and cervical smears cannot entirely rule out the presence of carcinoma since necrosis of the surface may result in smears which contain no recognizable tumour cells. Therefore, whenever the history or appearance of the cervix is suspicious, biopsy should be performed.

As Koss has indicated (1961), adenocarcinoma of the endometrium is somewhat more difficult to detect on cervical and vaginal smears. The cells do not exfoliate as abundantly as those from squamous epithelial tumours, and are often degenerated by the time they appear in the vaginal pool or cervical mucus. Endocervical or endometrial aspiration smears disclose the presence of this lesion in 80 to $90 \%$ of cases and may be used if the patient's age or symptoms so indicate. The presence in cervical or vaginal smears of old blood or necrotic cellular debris not otherwise explained may also suggest the need for endometrial smears. In large surveys, adenocarcinomas of the uterine body may constitute 3 or $4 \%$ of the unsuspected tumours found.

Carcinoma of the Fallopian tube and ovary, or peritoneal carcinomatosis may be represented in vaginal smears. We have seen several instances of the latter in the course of rendering hormonal evaluations on vaginal smears of patients receiving therapy for carcinoma of the breast.

\section{The Bronchus}

The Papanicolaou technique was rapidly applied to the diagnosis of pulmonary carcinoma as well. Nor were these efforts without precedent. Since Beale found tumour fragments in sputum in 1860 , many investigators have reported carcinoma cells in sputum, and in 1897 , Hampeln urged wider use of sputum examinations for this purpose. Increasing interest was represented by Dudgeon and Wrigley (I935) who reported a wet film method of demonstrating particles of malignant growth in sputum. In 1943, Gowar examined sputum in 93 patients and correctly diagnosed 36 carcinomas, several of which were operable. Wandall in 1944 published the largest series up to that time. Papanicolaou first reported the successful diagnosis of lung carcinoma in 22 of 54 patients by sputum examination in 1946. With Watson, Cromwell and 


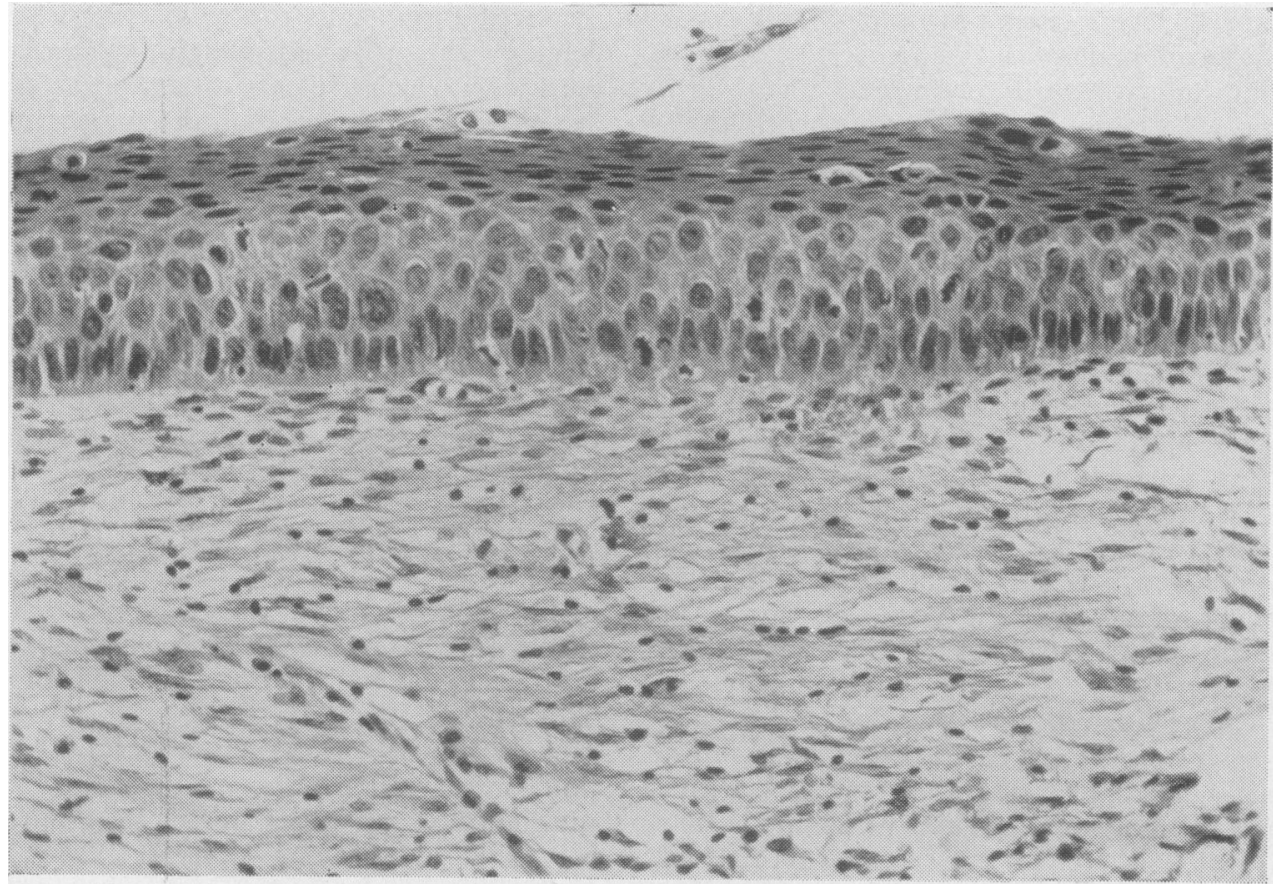

(a) Atypical hyperplasia of cervical epithelium. H+E. x 400 .

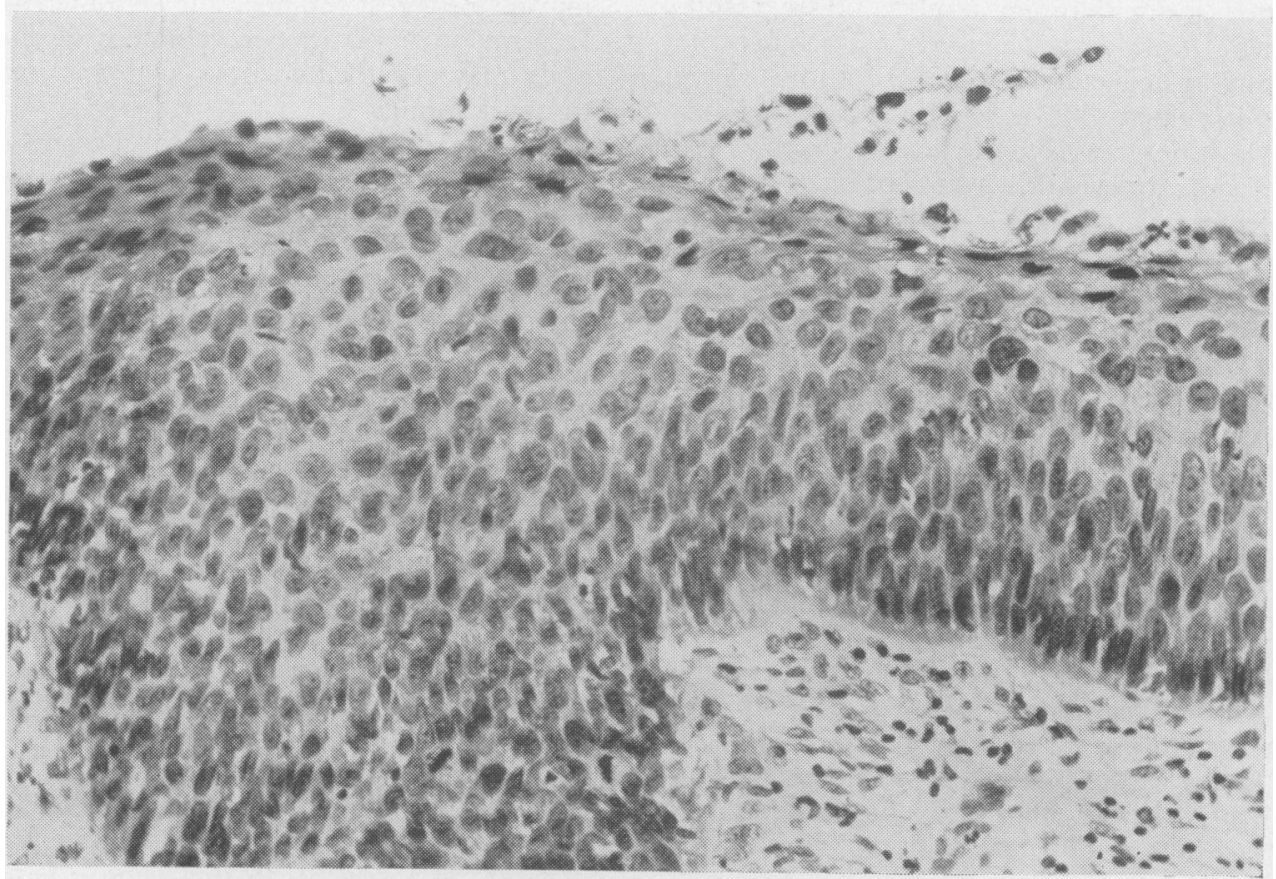

(b) In situ carcinoma. H+E. $\mathrm{x} 400$.

Fig. 3 . 
Craver he reported the results of sputum examination in 1,200 cases in 1949 . Meanwhile, Herbut in 1946 , and McDonald and Woolner in 1947 , also reported successful identification of malignant cells in bronchial secretions and in sputum, respectively, in large numbers of patients. More recently, Hampson (1956), Steele (1957) and Umiker (1960), have reported similar results.

It may be concluded from these reports that lung cancer can be detected by examination of sputum and bronchial secretions in approximately $80 \%$ of persons with the disease. Bronchial biopsy, on the other hand, has been reported to give positive results in as few as $27 \%$. A recent review (Valaitis, Leader, Chomet and McGrew, I96I) of cases of pulmonary carcinoma at a Veterans' Hospital in Chicago indicates, in adtion, that 10 to $15 \%$ of the X-ray exminations on these patients may fail to disclose the true nature of the disease. Large numbers of patients now undergo thoracic exploration on the basis of X-ray and cytologic evidence without confirmatory positive biopsy in the hope of improving the operability and survival rate in this disease.

Care must be exercised in obtaining specimens of sputum and bronchial secretions for cytologic examination. It has been found that tumour cells may be produced in sputum rather irregularly, and that diagnostic accuracy is increased many fold with the examination of multiple fresh morning sputum specimens. The patient must be observed and instructed in the production of a deep cough specimen and the sputum must either be processed at once or mixed with $50 \%$ alcohol in saline. Four to eight smears are prepared from each sputum specimen. The value of direct smears obtained at bronchoscopy or saline washings of the bronchi varies with the interest and care taken by the bronchoscopist and the laboratory staff. Many reports indicate difficulty in obtaining suitable material from bronchoscopy and better results from multiple sputum specimens. It has been noted by several observers that sputum specimens obtained two to 48 hours after bronchoscopy are more likely to contain tumour cells than either the bronchoscopic secretions or sputum taken prior to bronchoscopy. Bronchoscopy is not always done until after suspicious or positive cytologic findings have been reported, however. Techniques have been developed recently to obtain a better concentration of malignant cells, both to lighten the burden of screening and to increase the detection rate. Beckerman, Sproul and Barach (1958), reported a method of stimulating sputum production by means of an inhaled aerosol solution, and Klein, Pollack and Volk (1959), used variable pressure with an anæsthesia mask. Mucolytic agents have been used by a number of investi- gators to permit concentration of the epithelial cells by sedimentation or centrifugation and recently Chang, Anken and Russell (I96I) developed a method of enzymatic digestion and millipore membrane filtration to concentrate cells from sputum.

Although mass surveys of the population similar to those for the detection of female genital tract carcinoma cannot be seriously predicted at this time, the development of sputum-inducing methods and practical concentration techniques may well result in the discovery of increasing numbers of early, asymptomatic carcinomas of the lung in selected population groups.

\section{The Urinary Tract}

There had also been attempts to recognize tumours of the urinary tract from urine sediment prior to the development of the Papanicolaou method. Sporadic reports following that of Sanders (1 864) are adequately summarized by Deden in 1954. The reports of Papanicolaou and co-workers in 1945 and 1946 (Papanicolaou and Marshall), of Fremont-Smith, Graham and Meigs (1948) and Chute and Williams (1948) are representative of the early work. Deden's monograph in 1954 reported definite tumour cells identified in $78 \%$ of patients with carcinoma of the bladder and in three of six patients with carcinoma of the prostate. The largest series reported is that of Foot, Papanicolaou, Holmquist and Seybolt in 1958, reviewing 2,829 cases. They found malignant cells in urine sediment in $62 \%$ of transitional cell carcinomas of the bladder, ureter and pelvis, in $8 \%$ of renal carcinomas and in $15 \%$ of prostatic carcinomas. Many authors have stated that the study of urine sediment in suspected renal neoplasms is useless, but in 1954 , we (McGrew) reported successful identification of malignant cells in $50 \%$ of renal adenocarcinomas with no false positives. In a series now totalling 536 patients, $15 \%$ of the urinary tract malignancies were missed and $6 \%$ of the positive cytologic interpretations were erroneous. Seventy-two per cent. of the bladder carcinomas yielded positive cells in the urine sediment and another $15 \%$ were reported as suspicious. It is of some interest that of the 57 cases with positive cytologic reports, eight were not initially recognized as carcinoma on cystoscopic examination. Of 76 prostatic carcinomas examined by means of direct smears of prostatic secretions or post-massage urine sediment, approximately half were detected cytologically. Of 40 renal neoplasms, 20 of 28 renal cell carcinomas had suspicious or positive urine sediment cytology. Five of six transitional cell carcinomas of the pelvis, one of four Wilm's tumours and one sarcoma were correctly interpreted 
as malignant. A metastatic tumour was missed. 'There is some doubt as to the value of prostatic secretions obtained by massage in view of the possibility of disseminating malignant cells into the blood stream by trauma. Prostatic massage as a diagnostic procedure has been largely abandoned in this hospital and is looked on rather unfavourably by many surgeons. None the less, three positive prostatic secretions in our series were later confirmed in relatively young men with clinically benign prostatic disease. Herbut (1949) examined prostatic secretions in 480 patients, 66 of whom had carcinoma of the prostate. Fifty-four of these, or $82 \%$, had malignant cells in prostatic secretion. Similarly, Frank and Scott (1958), reported $84 \%$ positive cytology in 100 cases of prostatic carcinoma.

Cells exfoliated from renal cell carcinomas (hypernephromas or adenocarcinomas of the kidney) generally showed advanced degenerative changes in our experience and were few in number. Unfortunately, most of those with positive cytologic findings were advanced cases with extensive involvement of the pelvis and vessels of the kidney. However, four of them had not demonstrably invaded veins. Small and presumably curable renal adenocarcinomas have been detected cytologically by Fremont-Smith et al. (1948), McDonald and Woolner (1945), Bunge and Kraushaar (1950), and Foot and Papanicolaou (1949).

Thus, it may be anticipated that urinary cytology will disclose the presence of bladder malignancies in a high percentage of cases and will be almost as reliable in transitional cell carcinomas of the ureter or renal pelvis. If prostatic massage is utilized to obtain cells, clinically occult carcinoma of the prostate may be detected also, and the inclusion of urinary cytology in the study of renal diagnostic problems may have at least confirmative value.

Although some authors recommend mixing urine specimens with an equal volume of $70 \%$ alcohol, the cells adhere to the slide better and stain more reliably if the specimen can be obtained fresh, and the sediment smeared and fixed at once. Better representation of tumours of transitional and renal cell type is obtained by examining multiple specimens, best obtained after the patient has been up and moving about or after palpation of the area. Greatly improved cytologic results may be obtained following antibiotic therapy of a grossly infected bladder. Millipore filtration of previouslyfixed urine has been recommended by Solomon, Amelar, Hyman, Chaiban and Europa (1958) and Harpst, Ware and Eisenberg (196I), but it is doubtful that results in transitional cell car- cinomas would be greatly improved by this method since they usually exfoliate abundantly.

'The cytologic examination of urinary sediment $\stackrel{\mathbb{\infty}}{2}$ or prostatic secretion is usually requested for those $C$ patients with hæmaturia or other clinical signs $\underset{\overrightarrow{0}}{\overrightarrow{0}}$ leading to a suspicion of urinary tract malignancy. However, Crabbe, Cresdee, Scott and Williams? (r956), and Melamed, Koss, Ricci and Whitmore $\frac{\bar{\sigma}}{\bar{\omega}}$ (1959), have utilized urinary cytology to detect $\frac{\widetilde{\sigma}}{\sigma}$ early tumours in individuals exposed to bladder 0 carcinogens in industry.

\section{The Gastrointestinal Tract}

There were attempts to identify malignant cells $\vec{\omega}$ in secretions or washings from the stomach as long음 ago as 1882 (Rosenbach). Many false negative results were discouraging, however. Papanicolaou mentioned the detection of gastric malignancy in. I 946 and two years later Graham, Ulfelder and $\vec{\omega}$ Green (1948) reported malignant cells in saline washings of the stomach in five resectable cases of ली gastric carcinoma. An accuracy of around $60 \%$ o using vigorous lavage with Ringer's solution was reported by Seybolt, Papanicolaou and Cooper (I95I) and with the use of a balloon covered with an abrasive netting which was inflated in the की stomach, they were able to recognize $88 \%$ of $5 \mathrm{~d} \overrightarrow{\vec{T}}$ carcinomas (Cooper and Papanicolaou, r953 के A rotating brush which could be introduced into. the stomach and retracted into its sheath, wass devised by Ayre and Oren (1953), and Rubin and Benditt's method for lavage with buffered chymotrypsin (1955) enjoyed considerable popularity. More recently results in the range of 90 to $95 \%$ accuracy have been reported. These are summarized and the technique and criteria well illustrated by Schade (1959) and by Raskin, Palmer and Kirsner (196r).

Improvement in the detection of gastric carcinoma by the cytologic method is due to increasing experience and to measures preventing deterioration of the cells rather than to the use of any specific method for obtaining specimens, since these excellent results are obtained from saline washings as well as by the use of enzyme digestion techniques. Pernicious anæmia may cause nuclear $\rightarrow$ enlargement giving rise to errors in the interpretation of gastric material and the cytopathologist is $\mathrm{N}$ entitled to an intelligent clinical history in this, as in other types of specimens.

Anderson, McDonald and Olsen (I949) reported the use of cytologic examination of washings or direct smears from the nesophagus but had many false negative results. However, Johnson, Koss, Papanicolaou and Seybolt (1955) reported 70\% correct positive diagnoses in malignant tumours of the osophagus from washings and Rubin (1960), stated that 94 to $98 \%$ accuracy is possible. 
Lemon and Byrnes (1949) reported some success with the detection of carcinomas of the biliary tract and pancreas using duodenal drainage specimens. Others, including Raskin, Wenger, sklar, Pleticka and Yarema (1958), have obtained duodenal fluid with malignant cells in a very high percentage of cases.

Malignant tumours of the colon and rectum have also been subjected to cytologic detection utilizing direct smears obtained through the proctoscope or lavage spccimens. Wisseman, Lemon and Lawrence (1949), Bader and Papanicolaou (1952) and Chapman (1959), reported good results. Oakland ( $196 \mathrm{I}$ ) was able to identify malignant cells in saline lavage specimens from $83 \%$ of colonic carcinomas. Ulcerative colitis and polyps may produce atypical cells but with experience these can be distinguished from true malignancy.

Since gastrointestinal diagnostic procedures are rarely performed on patients without clinical evidence of disease, and since many of the neoplasms in question are notoriously silent in their early phases, the number of patients benefited by this means of diagnosis may be small. However, Shahon and Wangensteen (I960) reported a cancer detection study in which gastric analysis and stool examination were part of the general examination of asymptomatic patients. Nine thousand and thirty-five patients were examined in this way and of 296 with cancer, the gastrointestinal tract was the site of the lesion in 70 . One-third of these patients were found on review to be truly asymptomatic and the five-year survival rate for these was $50 \%$. Compared with the dismal survival figures usually reported for gastrointestinal malignancies, it would seem that procedures to detect asymptomatic cancer of the stomach and intestine would at least double the present cure rate.

\section{Carcinoma in Other Sites}

The diagnostic aspects of exfoliative cytology have been investigated in relation to many other areas of the body. Brill and Koprowska (1955) and Papanicolaou, Bader, Holmquist and Valk $\left(195^{6}, 195^{8}\right)$ published articles reflecting interest in the cytology of secretions from the breast. Spriggs (1954) and McCormack, Hazard and Belovich (1954) and Naylor (196r) have reported cytologic findings of value in cerebrospinal fluid. Lesions of the pharynx, nose and ear have been investigated by Friedman (I95I). Umiker and Lampe (I960) and Sandler (196r) have recently studied cytology of the oral mucosa and skin lesions have been investigated by Woodburne, Philpott and Philpott (1960). Ultmann, Koprowska and Engle (1958) and others have recommended the study of imprint smears of tissues, including lymph nodes, for the purpose of making more definitive or more rapid diagnoses.

\section{Exfoliative Cytology as an Aid to Therapy}

There are several areas in which the study of exfoliated cells may be helpful in directing therapy of malignant disease. Vaginal smears obtained from patients with carcinoma of the breast may yield information of value in planning the course of endocrine therapy. A woman whose vaginal smear displays marked estrogenic cffect is more likely to benefit from oophorectomy and androgenic therapy than one with little estrogenic effect. Studies of changes in vaginal smears of patients treated by radiation for carcinoma of the cervix were made by Graham (1947). In 195 I, she reported that patients could be divided into those showing good and poor responses to radiation. The patients displaying a good response werc eight or ten times more likely to survive five years than those showing a poor response. This information has been utilized in determining whether surgery should be performed in addition to radiotherapy. Present concepts of the criteria and significance of cellular radiation response are summarized in a 1959 symposium of the International Academy of Gynecological Cytology (Wied-Editor).

\section{Malignant Cells in the Blood}

Of considerable interest is the recent work on the isolation and demonstration of malignant tumour cells in the circulating blood. Although there were several reports between 1869 and $195^{\circ}$ of malignant cells found in the blood of patients with cancer, Engell (1955) was the first to succeed in isolating and identifying such cells. He lysed the erythrocytes with saponin and studied hæmatoxylin and eosin sections of cell blocks of the remaining sediment. Two years later Moore, Sandberg and Shubarg (1957) also identified tumour cells in hæmatologic preparations of blood after red blood cells had been removed by fibrinogen sedimentation. Roberts, Watne, McGrath, McGrew and Cole (1958), used fibrinogen sedimentation and separation of the remaining cells by flotation on bovine albumin of high specific gravity. Malmgren, Pruitt, DelVecchio and Potter (1958) lysed erythocytes and polymorphonuclear leukocytes with streptolysin- $\mathrm{O}$, concentrating the remaining cells on millipore filters. Seal (1959) devised a silicone flotation method and collected the cells thus obtained on millipore filters. Numerous variations on these isolation methods have been directed toward more complete recovery and better preservation of cells. Recently, Kuper, Bignall and Luckcock ( 1961 ) reported an ingenious method of eliminating polymorphonuclear leuko- 


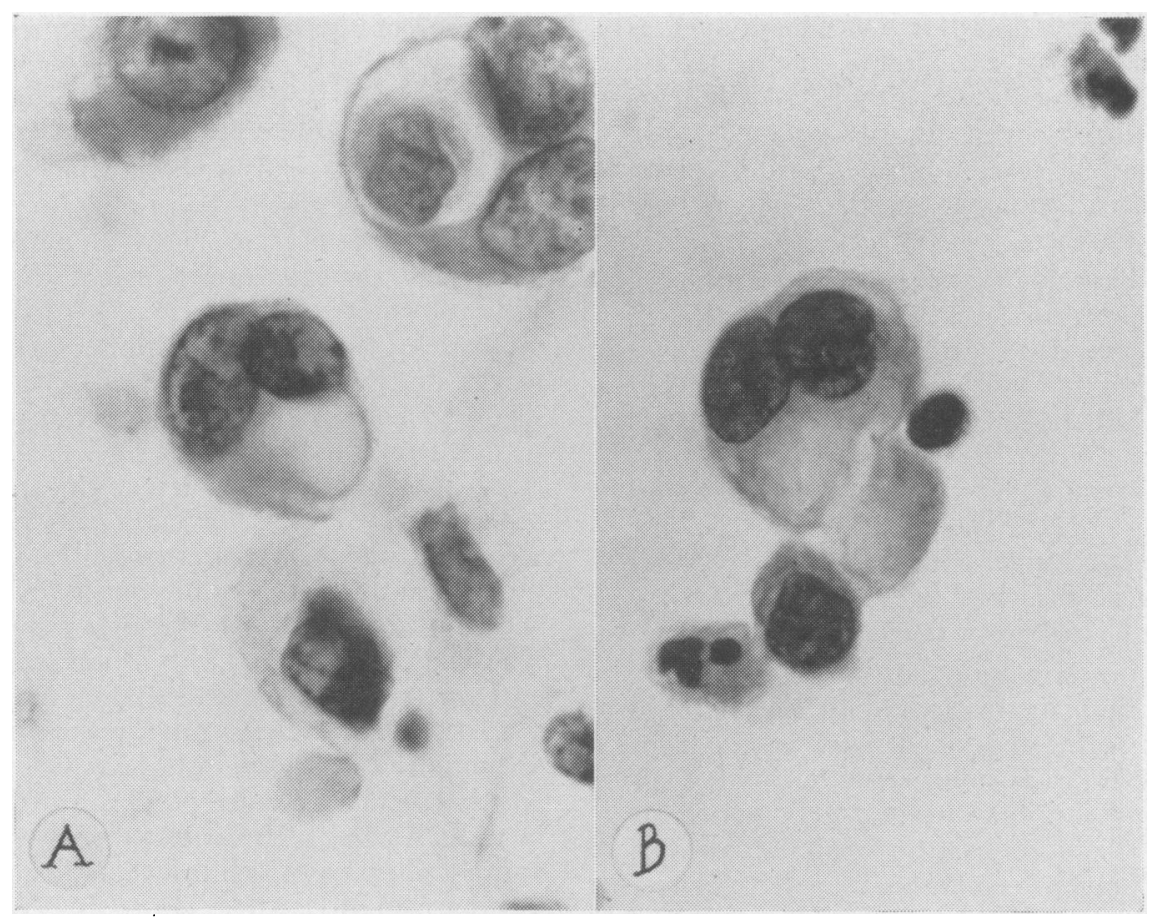

Fig. 4.-Cells from adenocarcinoma of the kidney: (a) Direct smear of cut surface of the tumour. (b) Blood from antecubital vein. Papanicolaou stain. x I 400 .

cytes with a magnet after they have ingested iron particles.

In general it has been found that malignant cells can be demonstrated in the blood in about $30 \%$ of patients with cancer (Fig. 4). Early small lesions rarely, if ever, yield positive blood samples and the majority of patients with positive samples have advanced, incurable disease. It is evident, therefore, that this technique has little value as a detection method.

If serial blood samples are drawn during operative procedures a definite correlation between manipulation and release of tumour cells into the circulation can be demonstrated. Pelvic examination, curettage, prostatic massage and vigorous scrubbing of skin overlying a tumour have resulted in 'showers' of cells. Fig. 5 shows the relative numbers of cells per cubic centimetre of blood in samples removed during resection of an ovarian carcinoma. From a pre-operative negative level, 38 cells per cubic centimetre suddenly appeared during pelvic examination after the patient had been anæsthetized. 'Twenty to 120 cells per cubic centimetre were found in samples taken during the surgical procedure. It is of interest that, within a few minutes after removal of a tumour, cells almost always disappear from subse- quent samples, even if metastases are known to be present at the time. Patients with advanced disseminated disease sometimes have a fairly constant $\stackrel{8}{\mathbb{Q}}$ number of malignant cells in blood samples. In $\overrightarrow{\vec{P}}$ such cases, reduction in the number of cells can be demonstrated during chemotherapy and also for several days following surgical procedures such as gastrostomy or exploration.

Speculation as to the prognostic significance of the presence or absence of tumour cells in the blood is rather premature at this time. Engell (1959) reported that patients with and without circulating malignant cells had essentially the same five to nine year survival rate, but Long, Roberts, McGrath, McGrew and Cole (1 960 ), noted $38 \%$ two to four year survival in patients whose blood samples were negative during their operations, while only $20 \%$ of those with positive samples during surgery survived.

It is hoped that this kind of information may be useful in the future in determining plans for chemotherapy or other measures. Modifications of diagnostic and surgical procedures to reduce the $\stackrel{\oplus}{\rightarrow}$ number of cells released into the circulation would seem to be clearly indicated at present.

The search for malignant cells in saline washings 


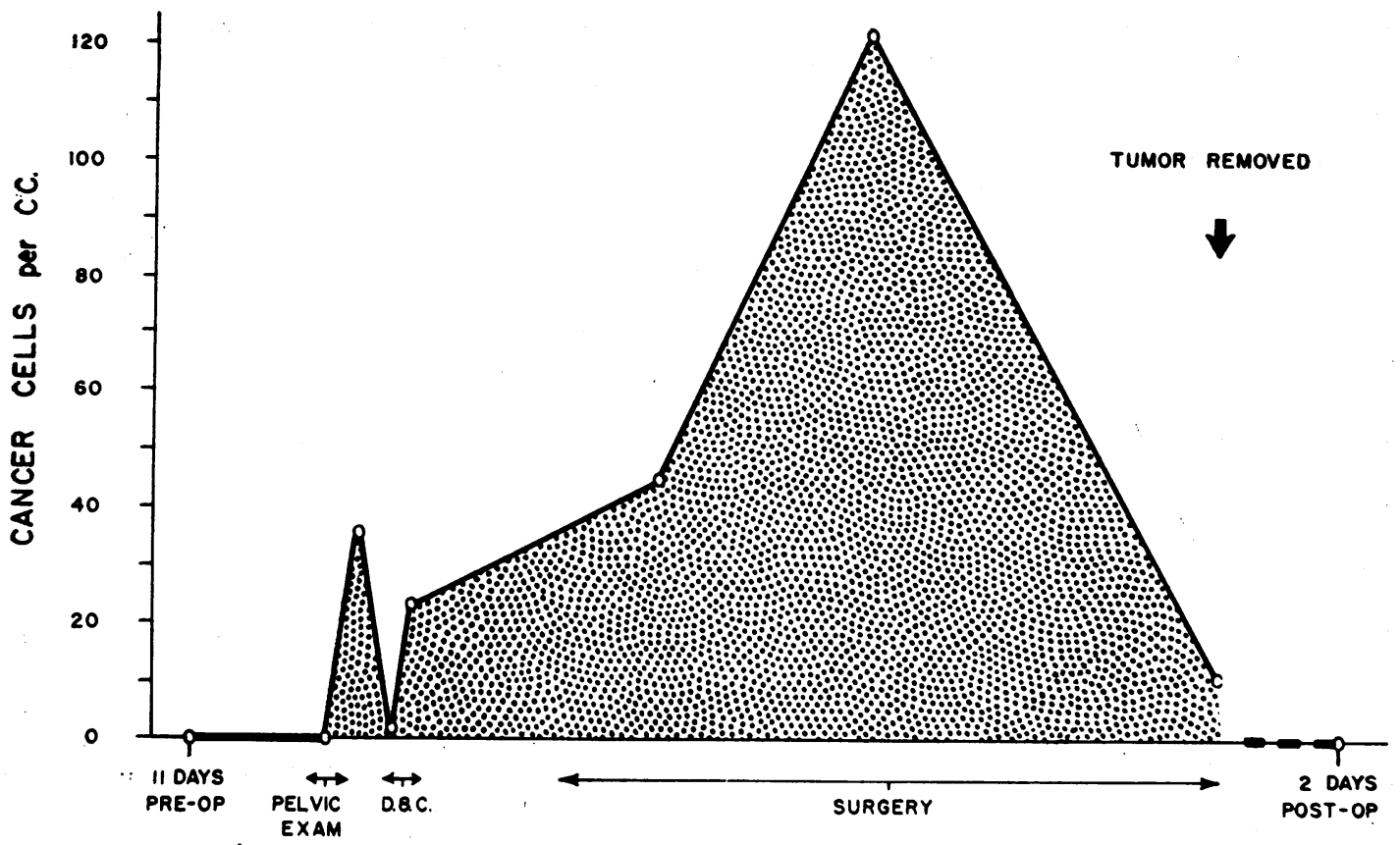

Fig. 5.-Cancer cells in the peripheral blood (antecubital vein) during resection of ovarian carcinoma.

of surgical wounds and of body cavities before and after operations for cancer have been carried out by Smith, Thomas and Hilberg (1958) and Burke and Sako (1960). These findings may also be of prognostic value and lead to improvement in therapy.

\section{REFERENCES}

Anderson, H. A., McDonald, J. R., and Olsen, A. M. (1949): Cytologic Diagnosis of Carcinoma of the Esophagus and Cardia of the Stomach, Proc. Mayo Clin., 24, 245.

Ayre, J., and Oren, G. (1953): A New Rapid Method for Stomach Cancer Diagnosis: The Gastric Brush, Cancer, 6, 1177 .

Bader, G. M., and Papanicolaou, G. N. (1952): Application of Cytology in Diagnosis of Cancer of the Rectum, Sigmoid and Descending Colon, Ibid., 5, 307.

Beale, L. S. (1860): Examination of Sputum from a Case of Cancer of the Pharynx and Adjacent Parts, Arch. Med., 2, 44.

Beckerman, H. A., Sproul, E. E., and Barach, A. L. (1958): An Aerosol Method of Producing Bronchial Secretions in Human Subjects, Dis. Chest, 33, 347.

Bizzozero, Grulio (1887): Handbuch der Klinischen Mikroskopie, 2nd German Edition. Erlangen: Eduard Besold.

Brill, R., and Koprowska, I. (1955): Diagnosis of Early Carcinoma of the Breast by Papanicolaou Technique, Amer. F. Surg., 90, ro16.

Bunge, R. G., and Kraushaar, O. F. (1950): Early Renal Malignancy, Diagnosis Preoperatively, F. Urol., $63,475$.

BURKE, E., and SAKo, K. (1960): Cancer Cells in Wound Washings in Head and Neck Surgery, Cancer, 13, 772.

Chang, J.P., ANken, M., and Russell, W. O. (1961): Sputum Cell Concentration by Membrane Filtration for Cancer Diagnosis, Acta Cytologica, $5,168$.

Chapman, B. M. (1959): Cytologic Diagnosis of Rectal and Colonic Conditions, Gastroenterology, 36, 501.

Chute, R., and Williams, D. W. (1948): Experience with Stained Smears of Cells Exfoliated in Urine in the Diagnosis of Cancer of Genitourinary Tract, $\mathcal{F}$. Urol., 59, 604.

Cooper, W. A., and Papanicolaou, G. N. (r953): Balloon Technique in the Cytological Diagnosis of Gastric Cancer, F. Amer. med. Ass., 151, 10.

Crabbe, J. G. S., Cresdee, W. G., Scott, T. S., and Williams, M. H. C. (1956): The Cytological Diagnosis of Bladder Tumours Amongst Dyestuff Workers, Brit. $\mathcal{Y}$. Industr. Med., 13, 270.

Deden, Carl (1954): Cancer Cells in Urinary Sediment, Acta radiol. (Stockh.), Suppl. 115.

Dudgeon, L. S., and Wrigley, C. H. (1935): Demonstration of Particles of Malignant Growth in Sputum by Means of a Wet Film Method, $\mathcal{F}$. Laryng., 50, 752.

ENGELL, H. C. (1955): Cancer Cells in the Circulating Blood, Acta chir. scand., Suppl. 201.

(1959): Cancer Cells in the Circulating Blood: A five to nine year Follow-up Study, Ann. Surg., 149, 457.

FIDLER, H. K., and BoYD, J. R. (1960): Occult Invasive Squamous Carcinoma of the Cervix, Cancer, 13, 764. 
Foot, N. C., and Papanicolaou, G. N. (1949): Early Renal Carcinoma-in-Situ, Y. Amer. med. Ass., 139, 356.

- Holmquist, N. D., and SEYBOLT, J. F. (1958): Exfoliative Cytology of Urinary Sediments: A Review of 2,829 Cases, Cancer, II, 127.

Frank, T., and Scotr, W. W. (1958): Cytodiagnosis of Prostatic Carcinoma: A Follow-up Study, F. Urol., 79, 983.

Fremont-Smith, M., Graham, R. M., and Meigs, J. V. (1948): Early Diagnosis of Cancer by Study of Exfoliative Cells, Y. Amer: med. Ass., 138, 469.

Frídman, I. (195 I): Exfoliative Cytology as Aid in Diagnosis of Tumours of Throat, Nose and Ear, F. Laryng., 65, 1.

GowAR, F. J. S. (1943): Cancer of the Lung, Value of Sputum Examination in Diagnosis, Brit. Y. Surg., 30, 193.

Graham, R. M. (1947): Effect of Radiation on Vaginal Cells in Cervical Cancer, Surg. Gynec. Obstet., 84, 153. , Ulfelder, H., and GreEN, T. H. (1948): Cytologic Method as an Aid in Diagnosis of Gastric Carcinoma, Ibid., 86, 257.

(1951): The Prognosis of Cancer of the Cervix by Vaginal Smear: Correlation with five-year results, Ibid., 93, 767.

HaMPELN, P. (1897): Uber den Auswurf Bein Lungencarcinom, Z. klin. Med., 32, 247.

HAMPSON, F. (1956): Exfoliative Cytology in the Diagnosis of Lung Cancer: Examination of One Laboratory's Results, Brit. med. F., ii, 146 r.

HaRPST, H. C., WARE, R. E., and Eisenberg, R. B. (196r): Exfoliative Cytology of the Urinary Tract: Evaluation of the Millipore Technique, Acta Cytologica, 5, 195.

Herbut, P. A. (1946): Bronchogenic Carcinoma: Diagnosis by Cytologic Study of Bronchial Secretions, f. Amer. med. Ass., 130, 1006.

(1949): Cytologic Diagnosis of Carcinoma of the Prostate, Amer. F. clin. Path., 19, 315.

Johnson, W. D., Koss, L. G., Papanicolaou, G. N., and Seybolt, J. F. (1955): Cytology of Esophageal Washings: Evaluation of 364 Cases, Cancer, 8 (5), $95 \mathrm{I}$.

Klein, M. R., Pollack, A., and VolK, H. (1959): A Machine to Collect Sputum for Screening for Lung Cancer. Trans. Sixth Annual Meeting I.S.C.C., p. 136 .

Koss, L. G (1961): 'Diagnostic Cytology'. Philadelphia: J. B. Lippincott Co.

KUPER, S. W. A., Bignall, J. R., and LUCKCock, E. D. (1961): A Quantitative Method for Studying Tumour Cells in Blood, Lancet, i (7182), 852 .

LEmon, H. M., and Byrnes, W. W. (1949): Cancer of the Biliary Tract and Pancreas, Y. Amer. med. Ass., 141, 254.

Long, L., Roberts, S., McGrath, R., McGrew, E., and Cole, W. H. (I960): Cancer Cells in the Blood Stream, Arch. Surg., 80, 639.

Lund, C. J. (1961): An Epitaph for Cervical Carcinoma, J. Amer. med. Ass., 175, 98.

Malmgren, A., Pruitt, J. D., DelVecchio, P. R., and Potter, J. F. (1958): A Method for the Cytologic Detection of Tumor Cells in Whole Blood, $\mathcal{Y}$. nat. Cancer Inst., 20, 1203 .

McCormack, L. J., Hazard, J. B., and Belovich, D. (1954): Neoplastic Cells in the Cerebrospinal Fluid. Trans̊ $\vec{\bullet}$ Second Annual Meeting of I.S.C.C., p. 116.

McDonald, J. R., and Woolner, L. B. (1947): Bronchogenic Carcinoma: Diagnosis by Microscopic Examination of Sputum and Bronchial Secretions, Proc. Mayo Clin., 22, 369.

, (1949): Cytologic Diagnosis of Cancer from Body Secretions and Fluids, S. Dak. Y. Med., 2, 216.

McGrew, E. A.: Bibliography on request.

(1954): Cytology of Urine Sediment in Renal Cell Carcinoma. Trans. Second Annual Meeting of I.S.C.C., p. I I I.

Melamed, M. R., Koss, L. G., RICCI, A., and WhItMORE, W. F. (r960): Cytohistological Observations on Developing Carcinoma of the Urinary Bladder in Man, Cancer, 13,67.

Moore, G. E., SANDBerg, A., and ShubarG, J. R. (1957): Clinical and Experimental Observations of the Occurrence and Fate of Tumor Cells in the Blood Stream, Ann. Surg., 146, 580.

NAYLOR, Bernard (1961): Cytologic Study of Intracranial Fluids, Acta Cytologica, 5, 198.

OAKLand, D. J. (1961): Diagnosis of Carcinoma of the Large Bowel by Exfoliative Cytology, Brit. F. Surg., 48, 353.

Papanicolaou, G. N. (1928): New Cancer Diagnosis. Proc. Third Race Betterment Conf., p. 528.

and TraUt, H. F. (1943): Diagnosis of Uterine Cancer by Vaginal Smear. Commonwealth Fund. Cambridge, Mass.: Harvard University Press.

and Marshall, V. F. (1945): Urinary Sediment Smears as Diagnostic Procedure in Cancers of the Urinary Tract, Science, ror, 519.

(1946): Cytology of Urinary Sediment in Known Neoplasms of Urinary Tract, Trans. Amer. Ass. gen.-urin. Surg., 38, 147 .

(1946): Diagnostic Value of Exfoliative Cells from Cancerous Tissues, Y. Amer. med. Ass., 131, 372.

(1954): 'Atlas of Exfoliative Cytology', Commonwealth Fund. Cambridge, Mass.: Harvard University Press.

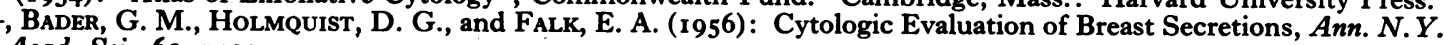
Acad. Sci., 63, 1409.

$\left.-,-1,-195^{2}\right)$ : Exfoliative Cytology of the Human Mammary Gland and its Value in the Diagnosis of Cancer and Other Diseases of the Breast, Cancer, $11,377$.

Pouchet, F. A. (1847): 'Theorie Positive de l'Ovulation Spontanée et de la Fécondation des Mammiferes et de l'Espèce Humaine, Basse sur l'Observation de Toute la Série Animale'. Paris: J. B. Bailliére.

Pryzbora, L. A., and Plutowa, A. (1959): Histological Topography of Carcinoma-in-Situ of the Cervix Uteri, Cancer, 12, 263.

Raskin, H. F., Wenger, J., Sklar, M., Pleticka, S., and Yarema, W. (1958): The Diagnosis of Cancer of the Pancreas, Biliary Tract, and Duodenum by Combined Cytologic and Secretory Methods: K. Exfoliative Cytology and a Description of a Rapid Method of Duodenal Intubation, Gastroenterology, 34, 996. -, Palmer, W. L., and KIrSnER, J. B. (196r): Morphologic Characteristics of Benign and Malignant Exfoliated

Roberts, S., Watne, A. L., McGrath, R., McGrew, E. A., and Cole, W. H. (1958): Technique and Results of Isolation of Cancer Cells from the Circulating Blood, Arch. Surg., 76, 334.

RosenBaCH, D. (1882): Ueber die Anwesenheit von Geshwulstpartkeln in dem durch die Magenpumpe entleerten; Mageninhalte bei carcinoma ventriculi, Dtsch. med. Wschr., 33, 452. 
Rubin, C. E., and BenditT, E. P. (1955): A Simplified Technique Using Chymotrypsin Lavage for the Cytological Diagnosis of Gastric Cancer, Cancer, 8, 1137.

(1960): Exfoliative Cytology of the Esophagus, Ibid., Bull. of Cancer Progress, 10, 90.

SANDERS, W. R. (1864): Cancer of the Bladder, Edinb. med. F., 10, 273.

SANDLER, H. C. (1961): The Detection of Early Cancer of the Mouth by Exfoliative Cytology, Acta Cytologica, 5 , 191.

Schade, R. O. K. (1959): A Critical Review of Gastric Cytology, Ibid., 3, 7.

SEAL, S. H. (1959): Silicone Flotation: A Simple Quantitative Method for the Isolation of Free-floating Cancer Cells from the Blood, Cancer, 12, 590 .

Seybolt, J. F., Papanicolaou, G. N., and Cooper, W. A. (1951): Cytology in Diagnosis of Gastric Cancer, Cancer, $4,286$.

Shahon, D. B., and Wangensteen, O. H. (1960): Early Diagnosis of Cancer of the Gastrointestinal Tract, Postgrad. Med., 27, 306.

Slate, T. A., Martin, P. L., and Merrit, W. J. (1957): The Value of Routine Cervical Smears in the Detection of Incipient Cervical Carcinoma in Pregnant Women, Amer. F. Obstet. Gynec., 74, 344.

Smith, R. R., Thomas, L. B., and Hilberg, A. W. (1958): Cancer Cell Contamination of Operative Wounds, Cancer, II, 53.

Solomon, C., Amelar, R. D., Hyman, R. M., Chaiban, R., and Europa, D. L. (1958): Exfoliative Cytology of the Urinary Tract, F. Urol., 80, 374.

Soule, E. H., and Dahlin, D. C. (1959): Cytodetection of Preclinical Carcinoma of the Cervix: Ten Years' Experience with Initial Screening and Repeat Cervical Smears, Proc. Mayo Clin., 34, I.

Spriggs, A. I. (1954): Malignant Cells in Cerebrospinal Fluid, $\mathcal{Y}$. clin. Path., 7, 122.

STEELE, C. H. (1957): Bronchogenic Carcinoma: Diagnostic Aspects of 228 Proved Cases, Laryngoscope (St. Louis), $67,137$.

Stockard, C. R., and Papanicolaou, G. N. (1917): Existence of a Typical Oestrus Cycle in Guinea Pig with Study of Histology, etc., Amer. F. Anat., 22, 225.

Ultmann, J. E., Koprowska, I., and Engle, R. L. (1958): A Cytological Study of Lymph Node Imprints, Cancer, II, 507 .

UMIKER, W. O. (1960): Diagnosis of Bronchogenic Carcinoma: An Evaluation of Pulmonary Cytology, Bronchoscopy and Scalene Node Biopsy, Dis. Chest, 37, 82 .

- and LAMPE, I. (1960): Oral Smears in the Diagnosis of Cancer and Premalignant Lesions of the Mouth, Oral Surg., 13, 897 .

Valaitis, J., Leader, S. L., Chomet, B., and McGrew, E. A. (196i): Unpublished data.

WANDall, H. H. (1944): The Study of Neoplastic Cells in Sputum as a Consideration in the Diagnosis of Primary Lung Cancer, Acta chir. scand., 91, Suppl. 93.

Watson, W. L., Cromwell, H., Craver, L., and Papanicolaou, G. N. (1949): Cytology of Bronchial Secretions:

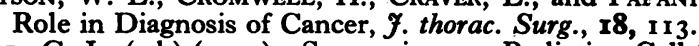

Wied, G. L. (ed.) (1959): Symposium on Radiation Cell Changes, Acta Cytologica, 3, 347.

Wisseman, C. L., Jr., Lemon, H. M., and LAWRENCE, K. B. (1959): Cytologic Diagnosis of Cancer of the Descending Colon and Rectum, Surg. Gynec. Obstet., 89, 24.

Woodburne, A. R., Philpotr, O. S., and Philpott, J. A., Jr. (1960): Cytologic Studies in Skin Cancer, Arch. Derm. Syph. (Chicago), 82, 85 I. 